\title{
Assessment of Surficial Loads of Heavy Metals in sediment of Ipo Stream and Sombriero River, Rivers State, Nigeria
}

\author{
*KPEE, F; NWINEEWII, JD
}

\begin{abstract}
Department of Chemistry, Faculty of Natural and Applied Sciences, Ignatius Ajuru University of Education Rumuolumeni Port Harcourt,
\end{abstract} Rivers State, Nigeria.*Corresponding author Email: kpeef@yahoo.com

\begin{abstract}
The concentrations of $\mathrm{Cd}, \mathrm{Ni}, \mathrm{Cu}, \mathrm{Pb}$ and $\mathrm{Fe}$ were determined in sediments and water samples of two aquatic systems after mineralization with $\mathrm{HNO} 3, \mathrm{HCl}$ and $\mathrm{HClO} 4$ and analyzed using Atomic Absorption Spectrophotometer model 507KL. The mean concentration obtained in sediments of Ipo stream were as follows Cd $(1.2$ - 1.7) $\mathrm{mg} / \mathrm{Kg}, \mathrm{Ni}(3.0-3.5) \mathrm{mg} / \mathrm{Kg}, \mathrm{Cu}(14.62-25.22) \mathrm{mg} / \mathrm{Kg}, \mathrm{Pb}(20.05-24.6) \mathrm{mg} / \mathrm{Kg}, \mathrm{Fe}(18.20$ - 24.82), while in water, in $\mathrm{mg} / \mathrm{L}$ was $\mathrm{Cd}(1.09-1.65), \mathrm{Ni}(3.09-3.72), \mathrm{Cu}(14.14-24.10), \mathrm{Pb}(20.00-24.20)$, and $\mathrm{Fe}(711-$ 907). In Sombreior sediment, the following concentration in $\mathrm{mg} / \mathrm{Kg}$ were obtained $\mathrm{Cd}(0.10-0.12)$, $\mathrm{Ni}(102-70.34)$, $\mathrm{Cu}(34.02-84.20) \mathrm{Pb}(18.22-23.05)$, and $\mathrm{Fe}(11780$ - 15642.2). However, in water the heavy metals occurred in the range $\mathrm{Cd}(<0.001-0.02), \mathrm{Ni}(64.21-82.01), \mathrm{Cu}(30.41-3961), \mathrm{Pb}(8.02-16.38)$, and $\mathrm{Fe}(712-872.0) \mathrm{mg} / \mathrm{L}$. The results showed that Ipo stream contained more heavy metals than Sombriero river and significant difference occurred in the mean concentration of heavy metals in Ipo stream and Sombreior river at $p<0.05$. The results showed that the major source of pollution of the study area is anthropogenic activities.
\end{abstract}

\section{DOI: https://dx.doi.org/10.4314/jasem.v22i5.13}

Copyright: Copyright $(02018$ Kpee and Nwineewi. This is an open access article distributed under the Creative Commons Attribution License (CCL), which permits unrestricted use, distribution, and reproduction in any medium, provided the original work is properly cited.

Dates: Received: 15 March 2018; Revised: 13 April: 2018; Accepted: 23 April 2018

Keywords: Surficial, loads. Heavy metals, aquatic

The pollution of the environment by toxicants in the Niger Delta area south-south Nigeria occur mostly from anthropogenic activities. This include discharge of untreated waste, mining, industrial processing, production of industrial and domestic substances. The toxicants terminates in the aquatic system as a result of erosion through water and precipitation from air.

In the Niger Delta area, aquatic organisms such as periwinkle, oyster, tilapia and many others are found in fresh and brackish water systems. The rivers are used for fishing and commercial purposes, such as shipping of crude oil and transportation of the inhabitants from hinterland to the riverine areas. Heavy metals are generated in this process and are partitioned in the sediment, water and the aquatic organisms. The sediments serves as sink and reservoir for the heavy metals and when the concentration of the heavy metals in the water has reduced, the metals can diffuse from the sediment to the water column. Emoyan et al (2006) stated that, due to the adsorption and accumulation of heavy metals in the sediment, the concentration is expected to be higher than those in the water above which can be carried by secondary pollution of the water column. It is on the bases of this, that this study was carried. Hence the objective of this paper is to report the concentration of heavy metals levels in the sediments of Ipo stream which is stagnant stream and Sombriero River- a fast flowing river.

\section{MATERIALS AND METHODS}

Study area. The Niger Delta region south-south Nigeria has many rivers, streams, ponds and creeks, but this study is restricted to Ipo stream situated in Omuagwa near Port Harcourt international airport and Sombriero River in Ahoada that transverse the east west road in Rivers state. Ipo stream is a stagnant water body while Sombriero River is a fast flowing rivers that flows from north south of Niger Delta and join other rivers and creeks that linked to the Atlantic Ocean. These two water bodies chosen are far apart and the sources of pollutant each received differs Sombreior River receive effluents mostly from rural area and water-run-off from cultivated farmland, while Ipo stream received particulate materials from aerosol of aeroplane and water run-off from farmland.

Sample collection: The core samples of sediment and water were collected from each river at the interval of three months for the period of one year. The samples were collected between the months of March to September 2016. The surface sediments were 
collected with bottom grab sampler at the depth of 0$5 \mathrm{~cm}$ and rapped in aluminum foil. The water samples were collected below the surface firm of the water of each river with a pre-rinsed plastic containers. In the Sombriero River, the plastic containers were placed against the direction of flow of the river while in Ipo stream, the container were place just below the surface of the water.

Sample preparation: Due to moist nature of the Niger Delta area, the sediment samples were air dried and oven dry at $105^{\circ} \mathrm{C}$ until a constant weight was obtained. The dried sediment samples were homogenized with motar and pestle and $5.0 \mathrm{~g}$ of each was weight and digested according the method of Association of Official Analytical Chemist (AOAC, 1995), while the water sample was digested according to the method described in (APHA, 1995). The fish samples were also oven dried at $105^{\circ} \mathrm{C}$ and digested with (aqua regia), a mixture of $\mathrm{HCl}$ and $\mathrm{HNO}_{3}$ in $1: 3$ ratio. The concentrations of heavy metals in each sample was determine using Atomic Absorption Spectropotometer model 5071 made in Japan in the Research Laboratory of the Ignatius Ajuru University of Education Port Harcourt.

Statistical analysis: One way analysis of variance (ANOVA) was used to analysed the results.

Ecological risk factor: This is defined as the product of toxic response and contamination factor, mathematically it could be expressed as:

$\mathrm{Er}=\operatorname{Tr} x C f$

Where $\mathrm{T}_{\mathrm{r}}$ is toxic response factor; $\mathrm{Cf}$ is the contamination factor.

Contamination factor is expressed as:

$\mathrm{Cf}=\frac{C m}{C b}$

where $\mathrm{Cb}$ is the background value of the metal, the background values of the metals in $\mathrm{mg} / \mathrm{Kg}$ are $\mathrm{Cd} 06$, $\mathrm{Ni} 68, \mathrm{Cu} 45, \mathrm{~Pb} 20$, and $\mathrm{Fe} 47200$ while $\mathrm{Cm}$ is the concentration of the metal in sediment, when $\mathrm{Er}<40$, low potential, $40<E r<80$ moderate potential, $80<$ $E r<160$ considerable potential, $160<E r<320$, high potential and $E r \geq 320$, very high. Interval for contamination factor, $\mathrm{Er}<0.1$ indicates very slight contamination, 0.10-0.25 slight contamination, 0.260.5. Moderate contamination, 0.51-0.75, severe contamination, and $0.76-1.00$ very severe contamination.

\section{RESULTS AND DISCUSSION}

The concentrations of the heavy metals in the samples of Ipo stream and Sombreio River is shown in Table 1 to 3 . The results showed that some of the heavy metals had elevated concentrations in all the samples and significant difference occurred in the mean levels of heavy metals at $\mathrm{p}<0.05$ two tailed. The non-essential elements are cadmium $(\mathrm{Cd})$ and lead $(\mathrm{Pb})$. These elements are not required even at trace amount for the metabolism of living organisms. Cadmium $(\mathrm{Cd})$ in the sediment samples occurred in the range of $<0.001$ to $1.36 \mathrm{mg} / \mathrm{Kg}$ in Ipo and Sombriero.

Elevated levels of $\mathrm{Cd}$ was recorded in the sediment samples of Ipo streambed when compared to the mean levels in Sombriero River. This may be attributed to the fact that Ipo stream is a stagnant water and imputs of any pollutants to the stream remain and sink to the sediment and are partitioned among the different phases of the stream. Cadmium recorded the highest mean concentration of $17.0 \mathrm{mg} / \mathrm{kg}$ in the month of September and the least in June. In the Niger Delta area the rainy season span from the month of May to October. The elevated concentration of $\mathrm{Cd}$ in September may result from the fact that in the rainy season, more waste and effluents are carried in drains to the stream. The results obtained in this study is higher than the findings of Horsfall and Spiff (2002); Kpee and Ekpete, (2014), where they reported low levels of $\mathrm{Cd}$ in sediment of New Calabar River. The sources of cadmium to the Ipo stream is mostly from pigments, plastics, coated fabrics, textiles, rubber, paints and erosion or run-offs from farmland where phosphate fertilizer was applied to crops. The levels of cadmium $(\mathrm{Cd})$ in water sample of Ipo stream followed similar trend with levels in the sediment, which occurred in the range of 1.09 to $1.65 \mathrm{mg} / \mathrm{L}$ and the highest concentration also occurred in September. The contamination factor and ecological risk factor for $\mathrm{Cd}$ showed the range of 0.13 to 2.13 for Ipo and Sombriero sediment, indicating that both fall within slight contamination to very severe contaminated, while ecological risk (Er) factor for Sombriero River was $<40$, indicating low potential ecological risk in all the months, while in Ipo stream, $40<\mathrm{Er}<80$ was obtained indicating moderate potential ecological risk. Table 4 revealed the ecological risk factor values for each element. In Ipo/Sombriero sediment respectively. The highest ecological risk factor of 63.9/37.5 occurred in the month of September and the least in June. Lead $(\mathrm{Pb})$ concentration is shown in Table 1 to 3 , the concentrations occurred in the range of 20.05 to $24.6 \mathrm{mg} / \mathrm{Kg}$ in the sediment and 20.00 to $24.20 \mathrm{mg} / \mathrm{l}$ in the water of Ipo stream. Lead had similar distribution trend as cadmium in Ipo stream. However, in Sombriero River, range of 18.22 to $23.05 \mathrm{mg} / \mathrm{kg}$ occurred in the sediments and 8.02 to $16.38 \mathrm{mg} / \mathrm{l}$ in 
water samples. Lead $(\mathrm{Pb})$ is non-essential element distributed to the environment as a result of anthropogenic activities and it is used in the production of many household materials such as paint, pigment, electricals, electronic, fertilizer and pesticides. The concentration of $\mathrm{Pb}$ in Sombriero River may due to transportation, spillage of crude oil and erosion from motor mechanic workshops in Ahoada metropolis and along east/west road.
Table 1: Heavy metals levels in sediment and water of lpo stream

\begin{tabular}{|c|c|c|c|c|c|}
\hline & \multicolumn{5}{|c|}{ Heavy metals in sediment $\mathrm{mg} / \mathrm{kg}$} \\
\hline Month & Cd & $\mathbf{N i}$ & $\mathrm{Cu}$ & $\mathbf{P b}$ & $\mathbf{F e}$ \\
\hline March & $1.3+1.1$ & $3.50+2.72$ & $17.41+162$ & $20.05+12.6$ & $2462+25.0$ \\
\hline June & $1.2 \pm 1.0$ & $3.0 \pm \overline{2} .96$ & $14.62 \pm 13.20$ & $24.6 \pm \overline{2} 3.0$ & $2225 \pm 65.0$ \\
\hline September & $1.7 \pm 1.5$ & $3.2 \pm 2.9$ & $25.2 \pm 15.60$ & $21.6 \pm 21.0$ & $1820 \pm 101.2$ \\
\hline \multicolumn{6}{|c|}{ Heavy metals in water, $\mathrm{mg} / \mathrm{L}$} \\
\hline March & $1.09 \pm 0.28$ & $3 . \overline{45 \pm 3.10}$ & $15.8 \pm 12.1$ & $20.00+10.02$ & $8465 \pm 2.6$ \\
\hline June & $1.20 \pm 1.07$ & $3.72 \pm 2.84$ & $14.04 \pm 12.9$ & $24.20 \pm 22.0$ & $711+38$ \\
\hline September & $1.65+0.59$ & $3.09+2.80$ & $24.10+15.20$ & $21.05+10.30$ & $907+23$ \\
\hline
\end{tabular}

Table 2: Heavy metals in sediment of Sombriero River

\begin{tabular}{|c|c|c|c|c|c|}
\hline \multirow[b]{2}{*}{ Month } & \multicolumn{5}{|c|}{ Heavy metals in sediment $\mathrm{mg} / \mathrm{kg}$} \\
\hline & Cd & $\mathbf{N i}$ & $\mathrm{Cu}$ & $\mathbf{P b}$ & $\mathbf{F e}$ \\
\hline March & $0.09 \pm 0.02$ & $70.34 \pm 0.52$ & $34.02 \pm 0.54$ & $18.22 \pm 10.32$ & $11780 \pm 82.0$ \\
\hline June & $0.12 \pm 0.11$ & $102 \pm 2.7$ & $84.20 \pm 6.22$ & $19.28 \pm 2.71$ & $12114.0 \pm 34.0$ \\
\hline September & $0.10 \pm 0.04$ & $112 .{ }^{0} \pm 8.25$ & $71.01 \pm 3.81$ & $23.05 \pm 1.78$ & $15642.2 \pm 67.0$ \\
\hline \multicolumn{6}{|c|}{ Heavy metals in water in $\mathrm{mg} / \mathrm{L}$} \\
\hline March & $<0.001+0.00$ & $64.21 \pm 3.44$ & $30.41 \pm 0.11$ & $15.01 \pm 1.1$ & $750 \pm 3.9$ \\
\hline June & $0.010 \pm 0.00$ & $70.11 \pm 2.1$ & $32.02 \pm 0.9$ & $16.38 \pm 0.1$ & $712 \pm 2.7$ \\
\hline September & $0.020 \pm 0.00$ & $82.01 \pm 3.90$ & $39.61 \pm 0.72$ & $8.02 \pm 1.3$ & $872.0 \pm 7.9$ \\
\hline
\end{tabular}

Table 3: Contamination factor (Cf) for heavy metals in Ipo and Sombriero aquatic system

\begin{tabular}{llllll}
\hline Month & Cd & Ni & Cu & Pb & Fe \\
\hline March & $1.63 / 1.13$ & $0.1 / 2.01$ & $0.48 / 0.94$ & $0.24 / 0.190$ & $0.65 / 3.11$ \\
June & $1.5 / 0.13$ & $0.08 / 2.91$ & $0.41 / 2.34$ & $0.29 / 0.23$ & $0.58 / 3.19$ \\
September & $2.13 / 1.25$ & $0.09 / 3.2$ & $0.72 / 2.0$ & $0.6 / 0.27$ & $0.4 / 4.12$ \\
\hline
\end{tabular}

Table 4: Ecological risk factors for heavy metals in Ipo and Sombriero sediment

\begin{tabular}{lllll}
\hline Month & Cd & Ni & Cu & Pb \\
\hline March & $48.9 / 33.9$ & $0.05 / 10.05$ & $2.4 / 4.7$ & $1.2 / 0.95$ \\
June & $45 / 3.9$ & $0.4 / 14.55$ & $2.05 / 11.7$ & $1.45 / 1.15$ \\
September & $63.9 / 37.5$ & $0.45 / 16.0$ & $3.6 / 10.0$ & $3.0 / 1.35$ \\
\hline
\end{tabular}

Table 5: One way analysis of variance of the heavy metals levels in sediment of Ipo stream and Sombriero River

\begin{tabular}{llllll}
\hline Source & $\begin{array}{l}\text { Type III sum of } \\
\text { squares }\end{array}$ & df & Mean square & F & Sig. \\
\hline Corrected model & 467070131.834 & 9 & 51896681.315 & 113.294 & .000 \\
Intercept & 5401281.228 & 1 & 54010281.228 & 116.908 & .000 \\
Location & 53035629.937 & 1 & 53035629.937 & 115.780 & .000 \\
Metal & 207129428.169 & 4 & 51782357.042 & 113.044 & .000 \\
Location * metal & 206905073.727 & 4 & 51726268.432 & 112.922 & .000 \\
Error & 9161429.396 & 20 & 458071.470 & & \\
Total & 530241842.458 & 30 & & & \\
Corrected total & 476231561.230 & 29 & & & \\
\hline
\end{tabular}

Table 6: Analysis of variance of heavy metal in water of ipo stream and Sombriero River

\begin{tabular}{llllll}
\hline Source & $\begin{array}{l}\text { Type III sum of } \\
\text { squares }\end{array}$ & df & Mean square & F & Sig. \\
\hline Corrected model & $2274399.022^{\mathrm{a}}$ & 14 & 162457.073 & 10.607 & .000 \\
Intercept & 683335.878 & 1 & 683335.878 & 44.616 & .000 \\
Water & 2046659.876 & 4 & 511664.969 & 33.407 & .000 \\
Month & 48295.317 & 2 & 24147.659 & 1.577 & .239 \\
Water * month & 179443.829 & 8 & 22430.479 & 1.465 & .250 \\
Error & 229741.206 & 15 & 15316.080 & & \\
Total & 3187476.106 & 30 & & & \\
Corrected total & 2504140.228 & 29 & & & \\
\hline
\end{tabular}

Humans can be infected with $\mathrm{Pb}$ through food, air, and water. In food $\mathrm{Pb}$ occurred in lead solder used in food container such as canned milk, lead arsenate used as insecticide on food crops and on tobacco, leaded ceramics and grazes used in kitchenware. The contamination factor $(\mathrm{Cf})$ and ecological risk factor for $\mathrm{Pb}$ was lower when compared to the levels of $\mathrm{Cd}$. Highest contamination factor of $0.60 / 0.27$ was obtained in September in Ipo stream and Sombreio River. Highest values of ecological risk factor 3.0/1.35 was recorded in September. However, ecological risk factor in March, June and September were all $\mathrm{Er}<40$ indicating low potential ecological risk. In human, lead can accumulate in bones, liver, kidney and had the tendency to interact with protein especially those containing sulfhydryl group. $\mathrm{Pb}$ can also inhibit active transport mechanisms involving ATP to depress the activity of enzyme cholinesterase to suppress cellular oxidationreduction reaction Waldron and Stofen, (1974). The results of $\mathrm{Pb}$ obtained in this study agreed with the findings of Chindah et al (2009), Ogri et al (2011) in other rivers of the Niger Delta, and lower than the concentration obtained in the industrialized area (Schindler et al, 1980). The results of ANOVA indicated significant difference in the mean levels of $\mathrm{Cd}$ and $\mathrm{Pb}$ at $\mathrm{P}<0.05$ in sediment and water Table 5 and 6. Essential elements $\mathrm{Cu}, \mathrm{Ni}$ and Fe: The concentrations of the essential elements examined in this study varied with sample type and sites. The concentration of $\mathrm{Cu}$ in Ipo stream occurred in the range 14.62 to $25.2 \mathrm{mg} / \mathrm{Kg}$ in the sediment and 14.04 to $24.10 \mathrm{mg} / \mathrm{l}$ in the water. The highest concentration of $\mathrm{Cu}$ in both sediment and water samples was obtained in September and the lowest in June. In September, the dry season begins to set in and there is low influx of effluents which carries the pollutants to the aquatic system when compared to June which is the peak of rainy season. According to Ogri et al, (2011), at the peak of rainy season, the river and stream is diluted and the concentration of any pollutants becomes low. However, in the Sombriero River, the concentrations of $\mathrm{Cu}$ occurred in the range 34.02 to $54.20 \mathrm{mg} / \mathrm{Kg}$ in the sediment and 30.41 to $39.61 \mathrm{mg} / \mathrm{l}$ in water. 
Bowen, (1985) reported naturally occurring concentration of copper as 0.03 to $0.23 \mu \mathrm{g} / \mathrm{l}$ in surface seawater and 0.2 to $30 \mu \mathrm{g} / \mathrm{l}$ in freshwater system. However, elevated levels of $\mathrm{Cu}$ obtained in this study when compared to the natural levels reported by Bowen 1985 were very high. The contamination factor (Cf) for $\mathrm{Cu}$ in sediment of Ipo and Sombriero were $0.48 / 0.94,0.41 / 2.34$, and $0.72 / 2.0$ Table 3 . The result revealed that copper levels in Ipo and Sombriero streambed sediment falls within moderate contamination to severe contamination. On the other hand, ecological risk (Er) factor were low as the value were all $\mathrm{Er}<40$ Table 5. Similar results were obtained by Horsfall and Spiff, (2002), Emoyan et al (2006) and Kpee and Ekpete (2014), while elevated levels were reported by Bryan (1976) and Depledge (1987). The mean concentration of $\mathrm{Cu}$ in Sombriero River system followed a different trend where highest mean concentration of $\mathrm{Cu}$ was obtained in June. This may be due to the fact that in June more effluents were carried to the sediment and more geochemical adsorption of particulate materials occurred in the sediment. The concentration of $\mathrm{Cu}$ in the sediment of Sombriero Rivers doubles the levels obtained in water except in the month of March where similar concentration was obtained Table 2. Elevated concentrations of copper in human could be toxic, and some common effects of copper are irritation of nervous system, depression, necrotic changes in liver and kidney. Hans et al, (1981).

Nickel concentrations obtained in the sediment samples of Ipo Stream and Sombreior River are shown in Table 1 and 2 . The results showed that elevated concentrations of $\mathrm{Ni}$ was obtained in the samples. In Ipo stream, the concentrations of $\mathrm{Ni}$ occurred in the range 3.0 to $3.5 \mathrm{mg} / \mathrm{Kg}$ while 70.34 to $112 . \mathrm{mg} / \mathrm{Kg}$ was obtained in Sombriero River. The results indicated that elevated levels of nickel occurred in Sombriero streambed when compared to Ipo Stream. The concentration factor $(\mathrm{Cf})$ for $\mathrm{Ni}$ occurred as follows in sediment of Ipo and Sombreior River 0.1/2.01, 0.08/2.91, 0.09/3.2 in March, June and September respectively. The results revealed that the $(\mathrm{Cf})$ of $\mathrm{Ni}$ in both environments varied from slight contamination to very severe contamination as the value range from 0.08 to 3.2 Table 3. Very low potential ecological risk factor for $\mathrm{Ni}$ was obtained in sediment of both rivers as the values falls within 0.05 to 16.0 which is far lower than $\mathrm{Er}<40$ Table 4. On the other hand, the mean levels of nickel in the water sample is shown in Table 1 and 2. The results revealed that elevated levels of $\mathrm{Ni}$ was obtained in Sombriero River than in Ipo Stream. The +2 oxidation state of nickel is toxic particularly the tetracarbonyl $\left[\mathrm{Ni}(\mathrm{Co})_{4}\right]^{2+}$ and elevated levels of nickel in human can cause lung embolism, respiratory failure, birth defects, allergic reactions such as skin rashes mainly from jewelry (Duffus, 1980).

The concentration of iron is presented in Table 1 to 2 . The results revealed that iron $(\mathrm{Fe})$ recorded the highest mean concentrations in the samples when compared to $\mathrm{Cd}, \mathrm{Ni}, \mathrm{Cu}$ and $\mathrm{Pb}$. Iron occurred in the range $1820 \pm$ 101.2 to $2462 \pm 25.0 \mathrm{mg} / \mathrm{kg}$ and $11780 \pm 82.0$ to $15642.2 \pm 67.0 \mathrm{mg} / \mathrm{kg}$ in sediments of Ipo Stream and Sombreiro River respectively. Moreso, in the water sample, highest concentration of $\mathrm{Fe}$ was obtained in Ipo stream, which occurred in the range of 711 to $907 \mathrm{mg} / \mathrm{l}$, while in Sombreior River, the range 712 to $872 \mathrm{mg} / \mathrm{l}$ was obtained. Iron $(\mathrm{Fe})$ occurs in nature and can also be distributed to the environment through mining, smelting operation, and applications of fertilizer during cultivation of crops. The contamination factor (Cf) for Fe occurred as follows $0.65 / 3.11,0.58 / 3.19$, and 0.4/4.12 in March, June, and September in the Ipo and Sombriero River respectively. The $\mathrm{Cf}$ occurred in the range $0.4-3.19$, and revealed that the contamination factor $(\mathrm{Cf})$ for $\mathrm{Fe}$ showed moderate contamination. Iron $(\mathrm{Fe})$ is an essential element and as such it has no ecological risk factor. The concentration of iron $(\mathrm{Fe})$ in Ipo Stream and Sombriero River may be due to effluents from industries, water run-off from farmlands, where fertilizers and fungicides were used during cultivation of crops. Iron is an essential element and is toxic at elevated concentration, prolonged exposure of iron to human can caused inhibition activities of enzymes, fatigue, dizziness and loss of weight. Despite the toxicity of iron compounds, it plays important role biologically and technologically in man's life. The biological significance of iron is derived from its ability to undergo reversible oxidation reduction reactions and it is also an important component of hemoglobin.

Conclusion: Human activities such as transportation, the use of pesticides and fertilizers were the main sources of heavy metals to the water bodies. The study revealed that Ipo Stream which is a stagnant water contained elevated levels of heavy metals in water and sediment samples compared to Sombriero River which is a fast flowing river. Based on this, the inhabitants of Ipo settlement and its environs may be at risk of being poisoned from the consumption of water and aquatic organisms from the Ipo Stream.

\section{REFERENCES}

AOAC, (1995). Official methods of Analytical chemistry AOAC. International $16^{\text {th }}$ ed. Vol. (Cunnif), AOAC Int. Arlington, Virginia USA. 
APHA, (1995). Standard methods for the contamination of water and wastewater $19^{\text {th }} \mathrm{Ed}$ American Public Health Association.

Bowen, HM. (1985). The natural environment and biogeochemical cycles. In: D. Hutzinger (ed), the handbook of Environmental Chemistry Vol. 1 Part D: Springer-Verlag, New York, Pp 11-26.

Bryan, GW (1976). Some aspects of heavy metal tolerance in aquatic organisms. In: APM Lockwood (Ed) Effects of pollutants on aquatic organisms. Cambridge University Press. Cambridge, p 734 .

Chindah, AC; Braide, SA; Amakiri, J; Chikwendu, SON. (2009). Heavy Metal Concentrations in Sediment and Periwinkle (Tympanotonus Fuscatus) in the different ecological zones of Bonny River system, Niger, Delta. J. Open Environ. Pollut. Toxicol. 1: 93-106.

Depledge, MH (1987). Enhance copper toxicity resulting from environmental stress factor synergies. Comp. Biochem. Physiol. 87:119-125.

Duffus, J.H. (1980). Resource and Environmental Science series Eward Amold Publication Ltd. London. England. Environmental toxicology, 164 Pp.
Emoyan, OO; Ogban, EE; Akarah, E (2006). Evaluation of heavy metals loading of River Igana in Ekpan-Warri, Nigeria. J. Appl. Sci. Environ. Manage. 10(2):121-127.

Hans, G; Seiler, HS; Sigel, A (1987. Handbook on toxicity of inorganic compounds Marcel Dekker, New York.

Horsfall, M; Spiff, AI. (2002). Distribution and partitioning of trace metals in sediments of the lower reaches of the New Calabar River, Port Harcourt, Nigeria. Environ. Monitor. Assess. 78:309-326.

Kpee, F; Ekpete, OA (2014). Levels of trace metals in surface sediments from Kalabari creeks, Rivers State, Nigeria. J. Appl. Sci. Environ. Manage. 18(2):198-195.

Ogri, OR; Eja, ME; Malu, SP (2011). Seasonal Variations of Heavy Metal in Surface Sediments from Great Kwa River Estuary (G.K.R.E), South Eastern Nigeria. Intern. J. Appl. Environ. Sci. 6(2):155-164.

Waldron, HA. and Stofen, D. (1974). Sub-clinical lead Poisoing Academic Press New-York. 224 Pp. 